\title{
AS PEDRAS PORTUGUESAS DOS EDÍFICIOS E MONUMENTOS BRASILEIROS
}

\author{
Luís Lopes \\ Universidade de Évora, ECT, Dep. de Geociências e Instituto de Ciências da Terra \\ lopes@uevora.pt
}

Resumo: A utilização de rochas ornamentais portuguesas nos países da CPLP (Comunidade do Países de Língua Oficial Portuguesa), desde o Séc. XVI é historicamente conhecida e encontra-se profusamente documentada. Por exemplo, consultando a base de dados do SIPA (Sistema de Informação para o Património Arquitectónico, disponível em http://www.monumentos.pt) encontramos quase 33.000 referências à utilização da "pedra" em monumentos. Infelizmente, na maior parte dos casos não se refere especificamente que pedra, ou pedras, foram utilizadas em determinado monumento, pelo que algo ainda haverá a fazer para completar esta enorme e muito importante base de dados. Concretamente e no que concerne ao Brasil, são referidos 163 monumentos e edifícios onde pedra de origem portuguesa foi utilizada. Partindo do exemplo concreto da cidade de Évora, neste curto ensaio apresentamos os principais tipos litológicos, de origem portuguesa, que podemos encontrar em edifícios e monumentos históricos no Brasil.

Palavras Chave: rochas ornamentais portuguesas, lioz, mármore, monumentos

Abstract: PORTUGUESE DIMENSION STONES AND BRAZILIAN MONUMENTS. The use of Portuguese Dimension Stones in the countries of the CPLP (Community of Portuguese Speaking Countries) since the 16th century is historically known and widely documented. For example, by consulting the SIPA database (Architectural Heritage Information System, available at http://www.monumentos.pt) we find almost 33,000 references to the use of "stone" in monuments. Unfortunately, in most cases it does not specifically refer to what stone or stones were used in a given monument, so there is still something to be done to complete this huge and very important database. Specifically, as far as Brazil is concerned, 163 monuments and buildings where Portuguese origin stone of was used are mentioned. In this short essay, taking as example the stones used in the city of Évora, we present the main lithological types of Portuguese origin, which can be found in historical buildings and monuments in Brazil.

Keywords: portuguese dimension stones, lioz, marble, monuments

\section{INTRODUÇÃO}

A intensa e diversificada utilização de rochas em monumentos históricos, ilustra como estas obras evidenciam uma capacidade financeira capaz de suportar a utilização intensiva de materiais de construção com técnicas de exploração e beneficiamento assaz difíceis, morosas e onerosas. Ainda hoje e com máquinas altamente especializadas e robotizadas (as designadas CNC's), produzir as quantidades de blocos aparelhados necessários para edificar, por exemplo a Sé Catedral de Évora, levaria anos e teria custos muito elevados. Assim, a "Igreja", enquanto instituição, surge como polo permanentemente dinamizador de uma Arte e Indústria que se desenvolve em torno da pedra. A utilização continuada da "pedra" ao longo dos séculos, justifica e também permite compreender que a experiência adquirida coloque Portugal entre os principais fornecedores de obras em pedra a nível Mundial, tanto em modernas produções arquitetónicas como no fabrico e restauro de monumentos emblemáticos. Por exemplo, em Miami, Flórida (EUA), o monumento erigido em homenagem aos astronautas falecidos no desastre do vaivém Challenger, em 28 de janeiro de 1986, foi feito com o granito cinzento de Alpalhão; em 2011 o restauro das escadarias da Catedral de Notre Dame de Paris foi efetuado com calcários portugueses e os stands da Rolls Royce de todo o Mundo também estão a ser revestidos com pedra portuguesa. São apenas três exemplos, entre muitos outros, onde empresas portuguesas a trabalharem materiais portugueses deixam a sua marca em monumentos e edifícios de referência a nível mundial (Lopes, 2017 in prep.).

\section{ROCHAS ORNAMENTAIS DE PORTUGAL}

Existe em Portugal uma tradição milenar de exploração da pedra tanto como material de construção como elemento estrutural e/ou ornamental. Assim, não é de estranhar que, um pouco por todo o Pais, ainda tenhamos na atualidade pedreiras em atividade. Os materiais produzidos são, obviamente, condicionados pela geologia local. A produção de granitos paleozoicos concentra-se essencialmente no Norte, os calcários mesozoicos na região Centro e os mármores paleozoicos no Sul, os xistos também paleozoicos, tem menos importância económica e presentemente só têm unidades ativas a Norte (Figura 1).

Historicamente os granitos foram essencialmente utilizados como elemento estrutural e relativamente à sua utilização em edifícios e monumentos além fronteira durante a expansão marítima a partir do Séc. XV podemos afirmar que foram essencialmente utilizados em "padrões" que os marinheiros erigiam nos locais que aportavam ficando esse testemunho para memória futura.

De qualquer modo a sua utilização tem menor importância que a dos calcários ou mesmos dos mármores. Precocemente e nos locais de proveniência, calcários e mármores, devido sua à abundância enquanto matéria-prima, também foram utilizados como elementos estruturais (Figura 2). 


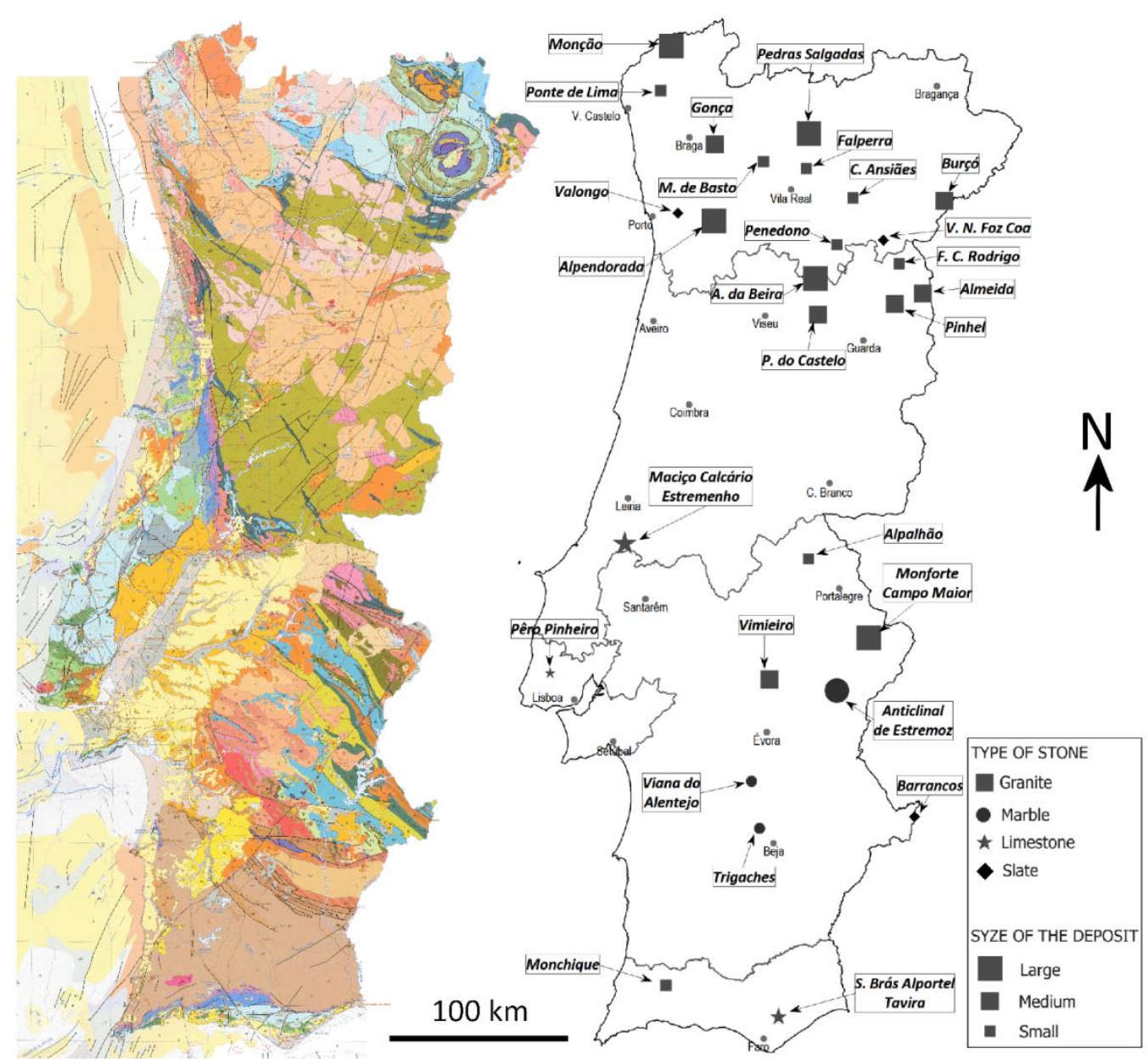

Figura 1. Mapa geológico esquemático de Portugal (adapt. de http://www.Ineg.pt) e localização dos principais centros produtores de rochas ornamentais (adapt. de Carvalho et al., 2013).
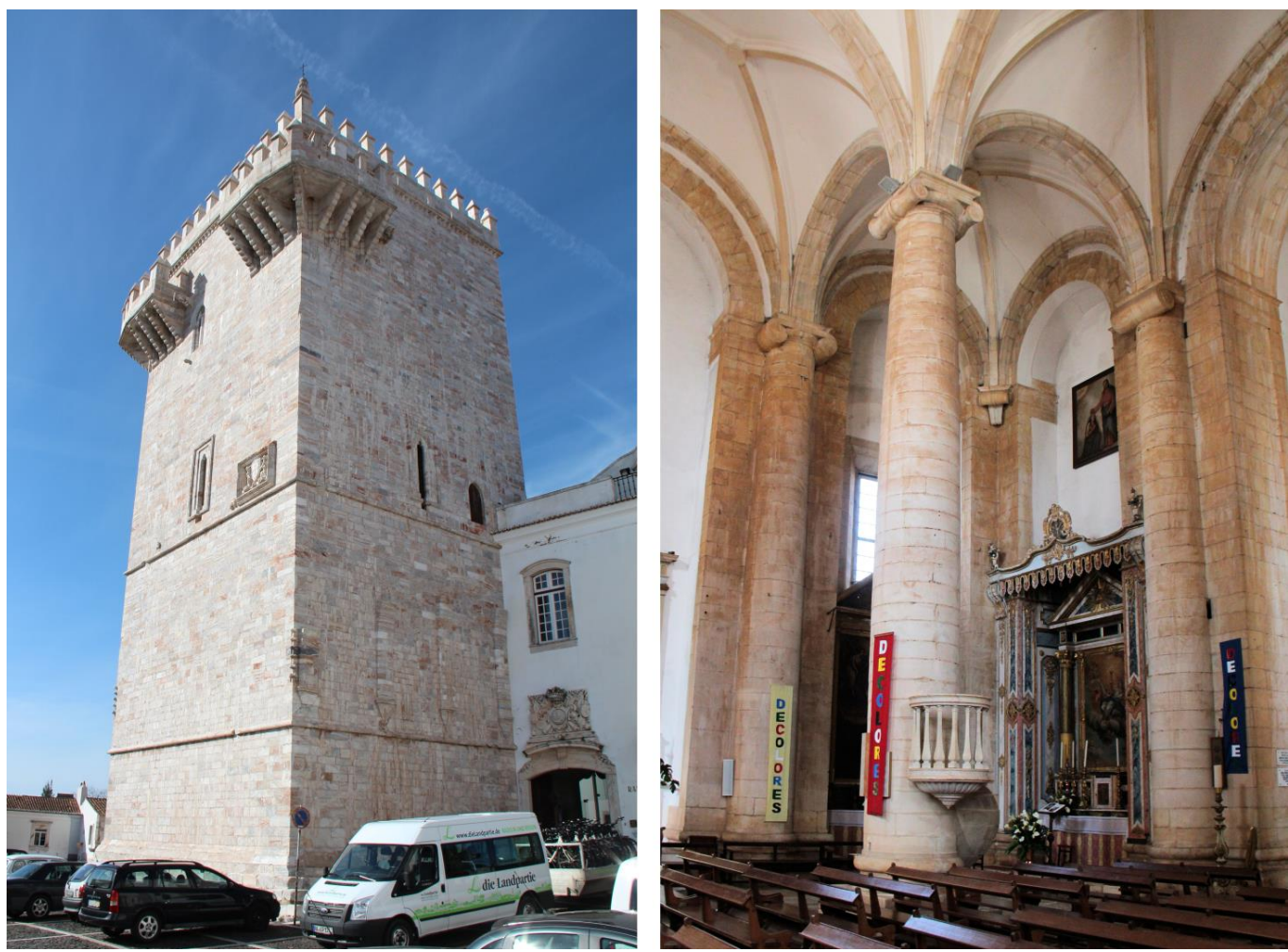

Figura 2. Exemplos da utilização de mármore como elemento estrutural na torre do Castelo e nas colunas da Igreja de Santa Maria, ambas na cidade de Estremoz, Alentejo. 
No entanto ao longo da história o seu papel tornou-se essencialmente ornamental e sinal externo de prestígio e distinção nos edifícios e monumentos em que são aplicados. Utilizando a cidade de Évora como exemplo, teremos uma ideia muito precisa dos materiais, técnicas e estilos historicamente utilizados. No caso particular, em Évora podemos recuar até ao Período Romano, Séc. I D.C.

\section{ROCHAS UTILIZADAS NOS MONUMENTOS}

Genericamente as rochas utilizadas nos monumentos de Évora podem separar-se em três grupos.

\section{afins)}

3.1. Rochas ígneas siliciosas (granitos e rochas

Sendo por excelência os materiais abundantes e disponíveis, não admira que as rochas siliciosas (granitos, gnaisses, migmatitos, granodioritos, quartzodioritos e dioritos) usualmente designadas por "granito", tenham sido utilizadas desde muito cedo.

Para além da sua utilização como elemento estrutural, fazendo parte do edifício e contribuindo para a sua robustez, também foram utilizadas como elementos decorativos. Para estes fins regista-se, contudo, um cuidado na seleção dos tipos petrográficos sendo privilegiados os homogéneos e de grão mais fino. As aplicações são diversificadas (pavimento, revestimento de paredes, colunas, arcos, estátuas, etc.). Entre as obras mais emblemáticas destacamos as gárgulas na Igreja/Ermida de São Brás que ao contrário dos restantes monumentos religiosos a Igreja de São Brás não apresenta externamente grandes estruturas em pedra (Figura 3), as estátuas na Igreja da Graça (Figura 4) e os robustos ornamentos da porta dos nós (Igreja do Carmo, Figura 5), atribuída a Diogo de Arruda (Espanca, 1950). Acontece que, expostas aos agentes atmosféricos, com o decorrer dos anos, estas rochas sofrem os efeitos da meteorização, bem patentes nos exemplos apresentados, com a exceção da Igreja do Carmo onde o estado de conservação é excelente em virtude, cremos nós, do resguardo em que se encontra inserido (Figura 5).

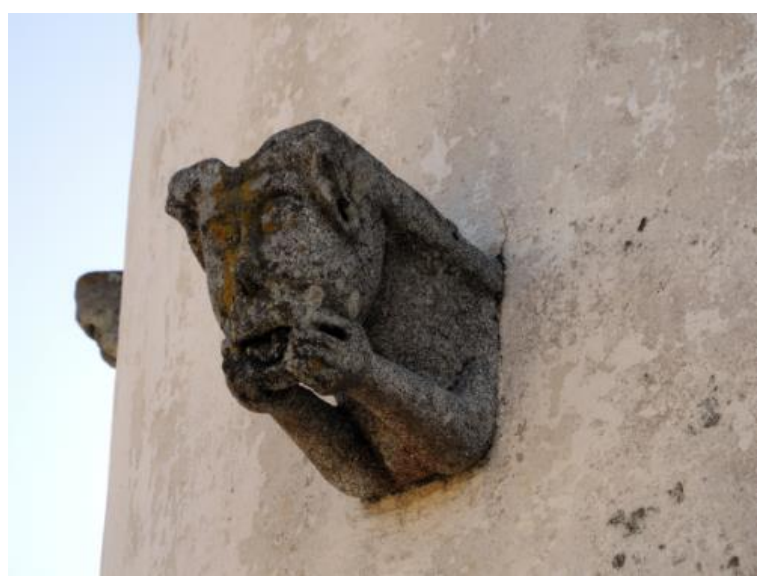

Figura 3. Gárgula em granito na Igreja de São Brás.

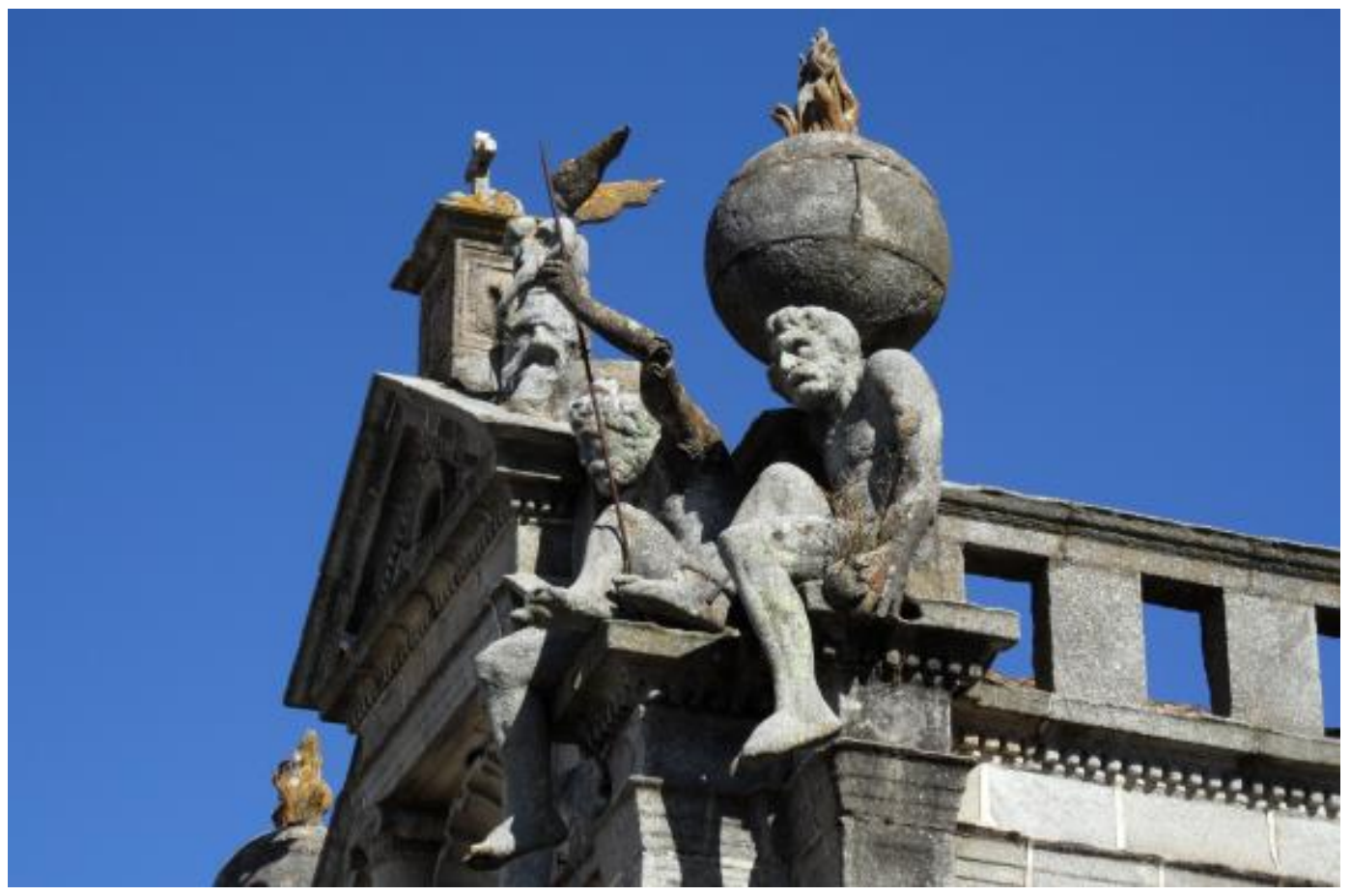

Figura 4. Pormenor das estátuas da Igreja dos Meninos da Graça onde se pode observar o avançado estado de meteorização em que as mesmas se encontram. 
O método de exploração, com incisões alinhadas onde cunhas de madeira seca eram inseridas e por intumescimento com água provocavam a rutura do granito, era usual no Período Romano e, na verdade, foi utilizado em vários monumentos romanos de Évora (Lopes et al., 2000). Este método extractivo marca uma inovação à utilização das rochas nos monumentos megalíticos. Ao invés de apenas serem selecionadas e aplicadas em bruto, no Período Romano as rochas são extraídas dos afloramentos mas, tendo em vista a sua utilização, irão ser transformadas adquirindo então a forma mais conveniente de acordo com o seu destino.

Neste grupo também aqui se incluem as rochas gnaisso-migmatíticas de composição mineralógica similar aos granitos mas com indícios claros de movimento, ou seja apresentam dobras que sugerem um fluxo quando, a vários quilómetros de profundidade, estavam sujeitas a altas pressões e temperaturas (Figura 6). Este grupo representa as rochas mais abundantes na região pelo que não admira que tenham sido profusamente utilizadas desde os monumentos megalíticos pré-históricos até aos passeios e arruamentos atuais. Quando inalteradas, normalmente estas rochas são de cor cinzenta clara e podem apresentar encraves (manchas mais ou menos regulares de materiais, normalmente de cor mais escura do que a rocha que os envolve). Estes encraves são facilmente identificáveis e em alguns casos, em função das características petrográficas que apresentam (textura, dimensão do grão e minerais presentes, etc.) é mesmo possível determinar aproximadamente o local de exploração da rocha que os contêm no terreno. Os fenómenos meteóricos de alteração destas rochas conduzem a que as mesmas adquiram tonalidades cremes ou castanhas. À superfície os minerais primários (quartzo, feldspatos potássicos e sódico-cálcicos, micas (branca ou moscovite e negra ou biotite), anfíbolas, entre outros, ditos acessórios) alteram-se e esta "degradação" da rocha não é mais do que uma adaptação dos seus constituintes às condições a que agora estão sujeitas (Figura 7). É um reflexo do tempo que passou por elas desde que foram retiradas dos afloramentos a que correspondem. Esta característica transforma-as em património do "Tempo" e constituí um fator intangível que enriquece a Cidade e contribuí para a sua identidade.

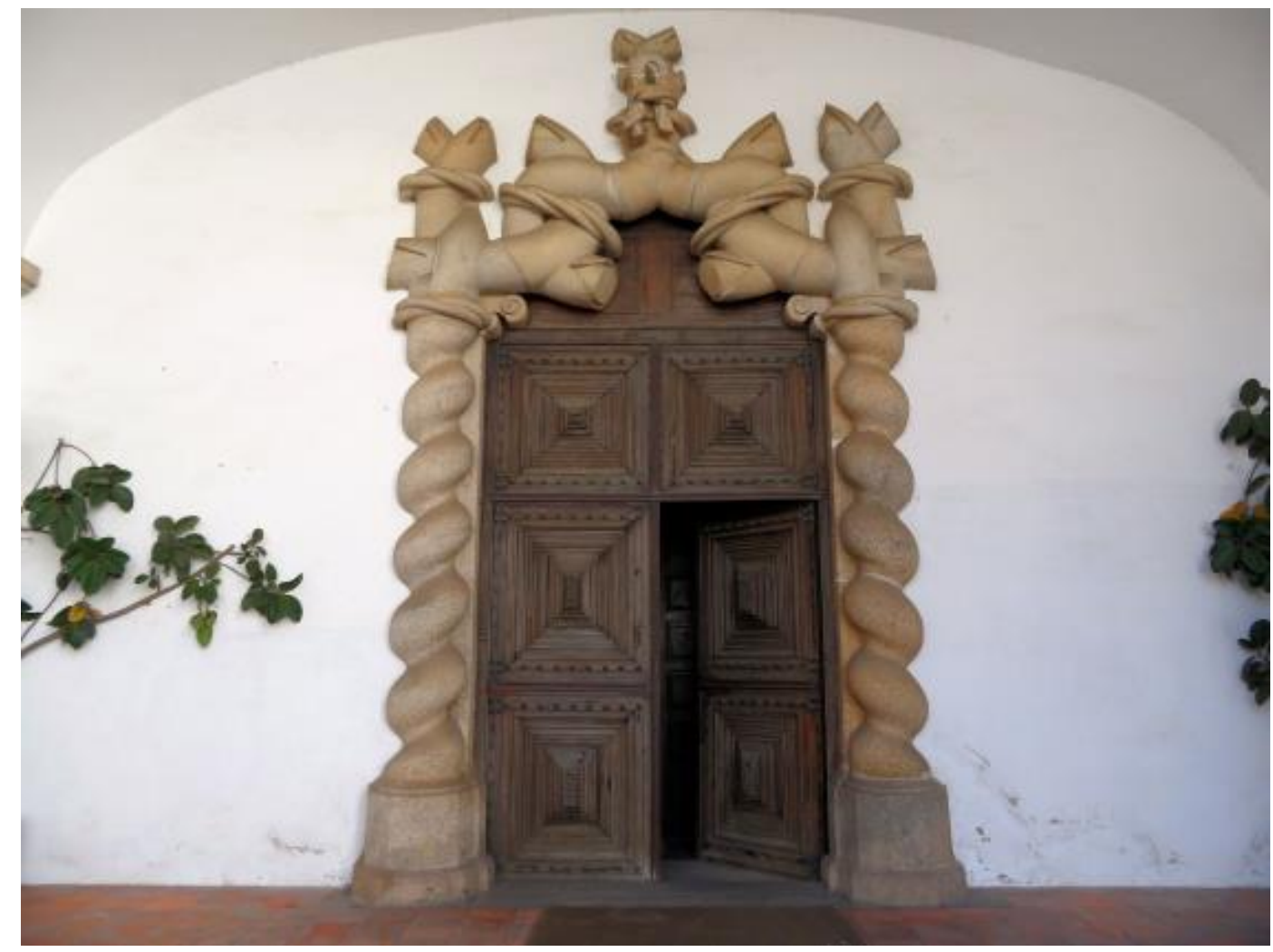

Figura 5. Portal de entrada da Igreja do Carmo, trabalhado em granito de Évora, que embora apresente alguns indícios de alteração denunciados pelos tons avermelhados, ainda assim revela um estado de conservação muito razoável. Esta fotografia foi tirada anteriormente ao restauro a que em 2013 o espaço da igreja foi sujeito. 


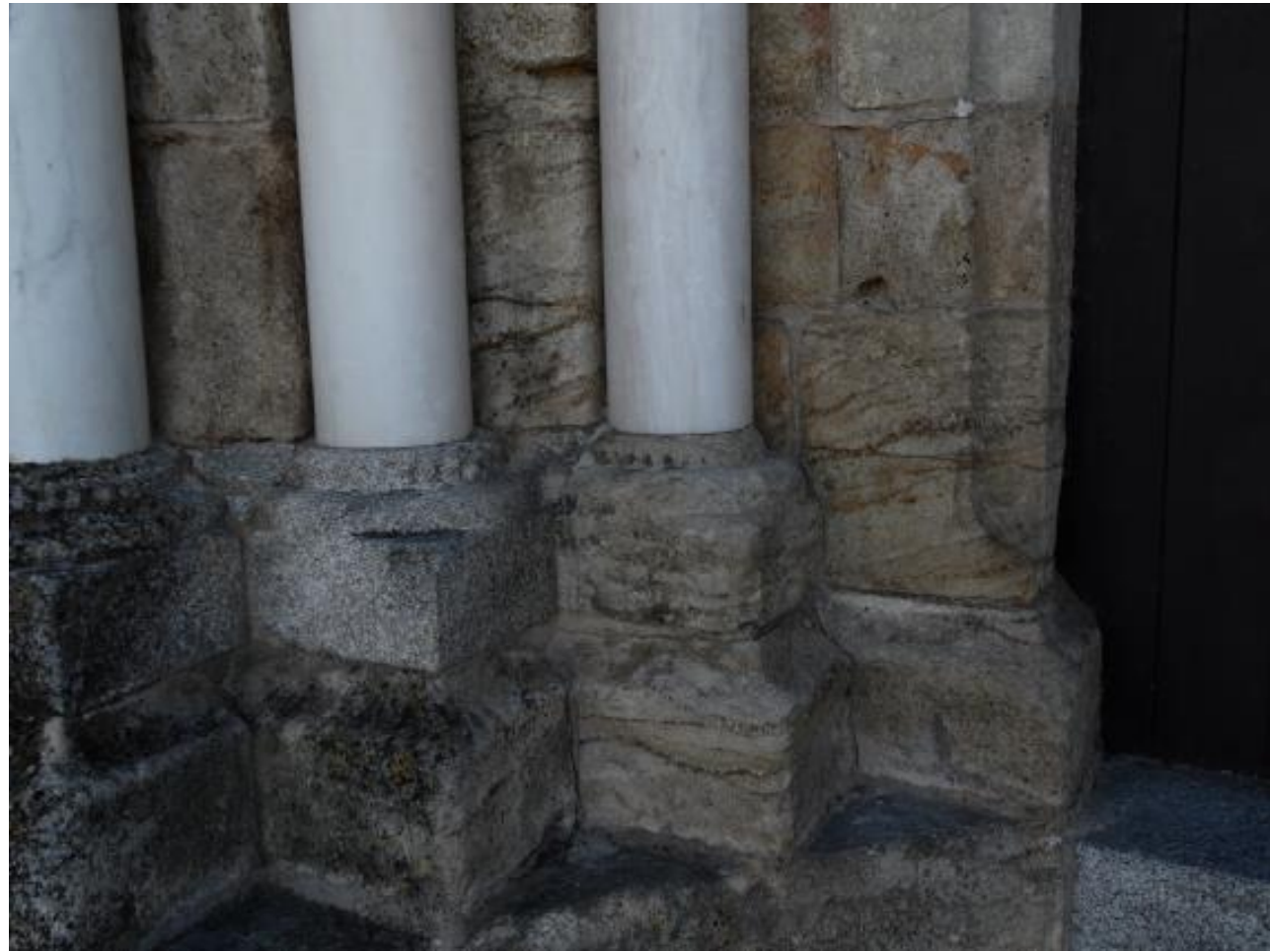

Figura 6. Pormenor da utilização de gnaisses/migmatitos na Igreja de São Francisco. A direita destacam-se o no aspeto bandado que as rochas siliciosas apresentam em contraste com uma textura homogénea que seria de esperar num granito e que se observa sob a coluna central. Na imagem observam-se ainda colunas em mármore branco de Estremoz recentemente colocadas no edifício em substituição de outras que por efeitos de dissolução, estavam num avançado estado de destruição, restando apenas um núcleo central irregular. Destacase ainda o mármore com laivos verdes relativamente raro mas, ainda assim característico dos mármores de Estremoz.

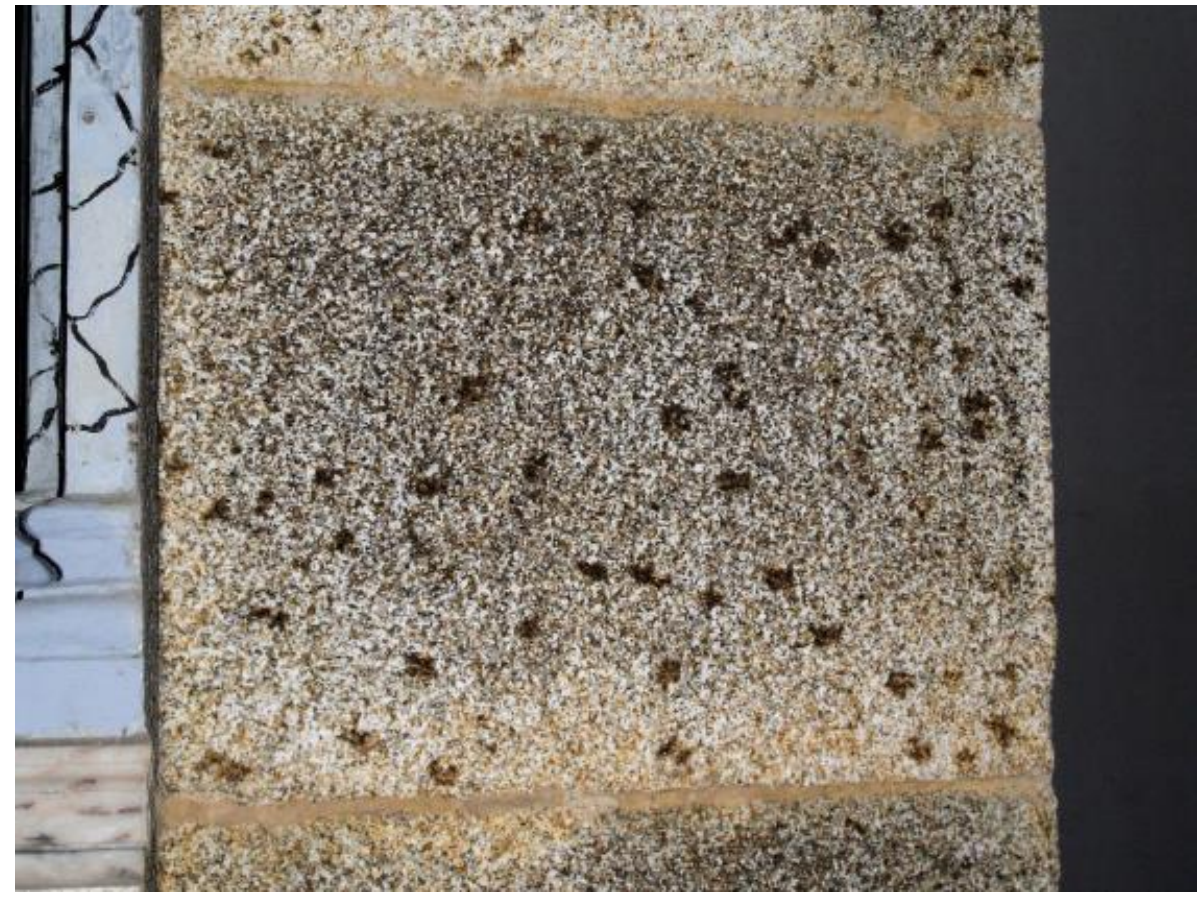

Figura 7. Detalhe da alteração dos cristais de biotite no granito cinzento utilizado na Igreja de Nossa Senhora da Pobreza.

3.2. Rochas metamórficas essencialmente carbonatadas - Mármores

Os mármores existem no Alentejo em várias localidades embora com características próprias que a Geologia de cada local pode explicar. Pela dimensão das explorações e pela intensa utilização é justo destacar os mármores do triângulo do "ouro branco" alentejano de Estremoz - Borba - Vila Viçosa. Este triângulo insere-se na estrutura geológica designada por anticlinal de Estremoz. 
Corresponde a uma estrutura elíptica com eixo maior superior a quarenta quilómetros desde Sousel a Norte até a Alandroal a Sul e eixo menor com cerca e dez quilómetros na região de Estremoz. Tridimensionalmente define um anticlinório com várias ordens de dobramento sendo o resultado da sobreposição de duas fases de deformação dúctil. Há registo de duzentas e oitenta e sete pedreiras ativas em 1987. Muitas destas eram pequenas explorações que coalesceram e tornaram-se maiores, outras simplesmente fecharam por vários motivos. Nos fins de 2016 prevalecem cerca de quarenta pedreiras que produzem mármores brancos, cremes, rosados, azuis, anil, e mais raramente esverdeados (Figura 8). Qualquer destas variedades apresenta diferentes intensidades de cor. Além disso pode ser homogénea, venada e/ou vergada, ou seja apresentar variações graduais entre as diferentes cores ou apresentar traços e linhas discretas de coloridas normalmente escuras (verde, preta, cinzenta, azul ou vermelha) que se destacam na matriz homogénea do mármore.

As variedades claras, de vários tons, são frequentemente utilizadas juntamente com as variedades cinzentas de modo a se obterem padrões e efeitos estéticos agradáveis ou ajudarem a compor determinados motivos (Figura 9).

Nos monumentos eborenses os mármores estão sempre presentes, sendo a maior parte proveniente do anticlinal de Estremoz. Também se conhecem explorações de mármores noutros locais, todavia apresentam características petrográficas (texturais, e mineralógicas) assim como padrões e cores tão característicos que, frequentemente, permitem uma rápida e acertada identificação. Estão nestas circunstâncias os materiais provenientes de: 1) Viana do Alentejo e 2) Escoural - ambos de granularidade média a grosseira e muito semelhantes, embora os de Escoural tenham granularidade ligeiramente maior; são mármores calcíticos bandados onde se destacam bandas rosadas, verdes, castanhas e cremes, raramente brancas com minerais acessórios (granada, anfíbolas, piroxenas, feldspatos, pirite, calcopirite vesuvianite e quartzo) facilmente identificáveis com o auxílio de uma lupa de mão); 3) Trigaches - mármores cinzentos-claros e escuros de grão médio a grosseiro e com a particularidade de cheirarem a ovos-podres $\left(\mathrm{SO}_{2}\right)$ quando percutidos; 4 Serpa - mármores verdes claros, homogéneos, de grão médio a fino com granadas castanhas claras e anfíbolas características (que neste caso correspondem a minerais brancos alongados); 5) Vera Cruz (Portel) - semelhantes aos de Serpa mas mais escuros e com bandado melhor definido e, 6) Vila Verde de Ficalho (Sobral da Adiça) - Estes apresentam a granularidade mais fina de todos os mármores alentejanos e por isso desenvolvem uma fatura concoidal característica, todas as cores referidas para os mármores de Estremoz também aqui se podem encontrar mas são mais frequentes as tonalidades brancas e cremes e azul claras. Atualmente, para além das pedreiras do anticlinal de Estremoz, apenas há extracção de mármores neste último local.

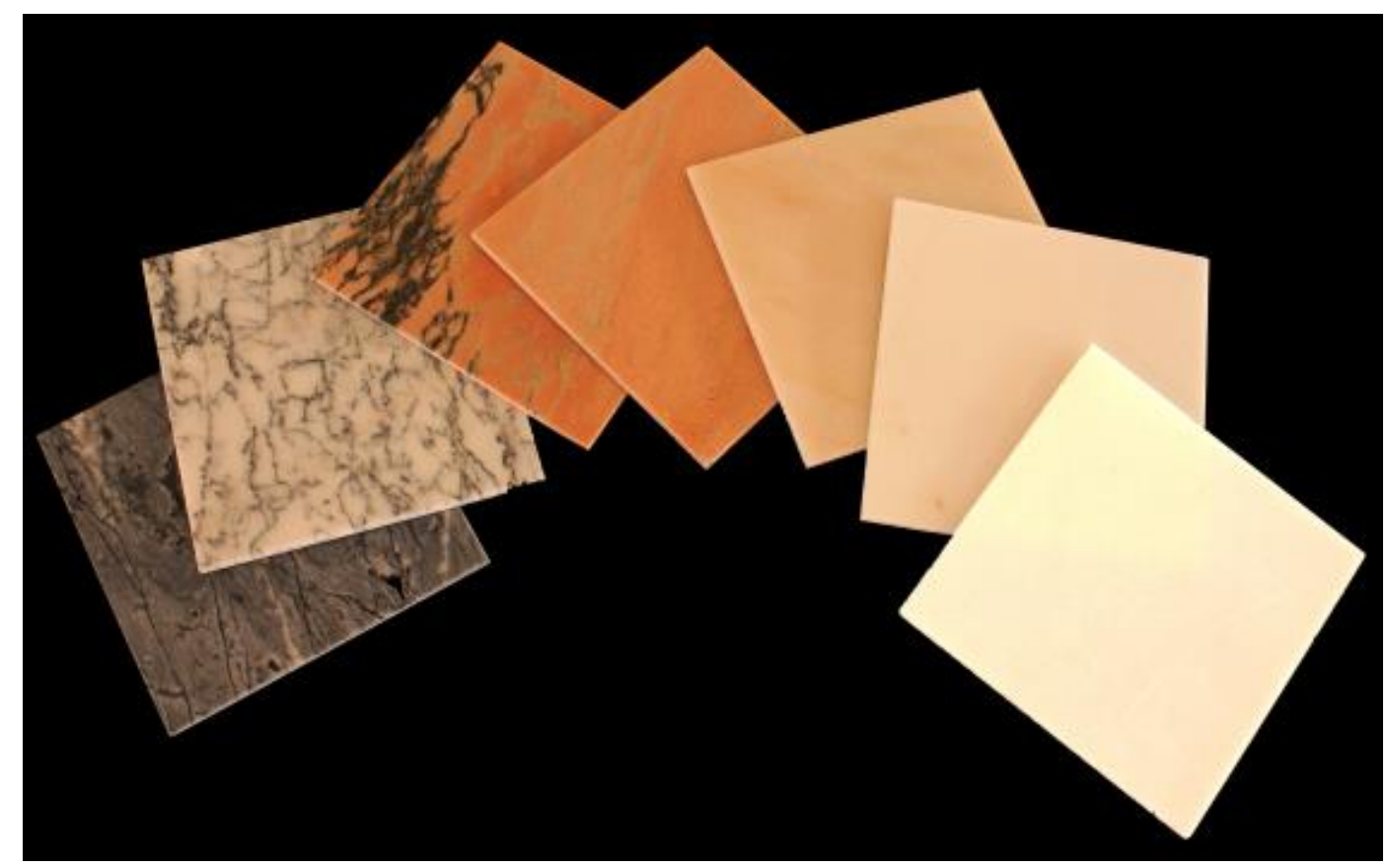

Figura 8. Algumas da variedades de mármore em ladrilhos quadrados com $30 \mathrm{~cm}$ de lado. Da esquerda para a direita: Ruivina da Lagoa, Pele de Tigre de Pardais, Rosa Vergado de Borba, Rosa Aurora, Creme de Pardais, Branco Rosado de Estremoz e Branco Vigária. 


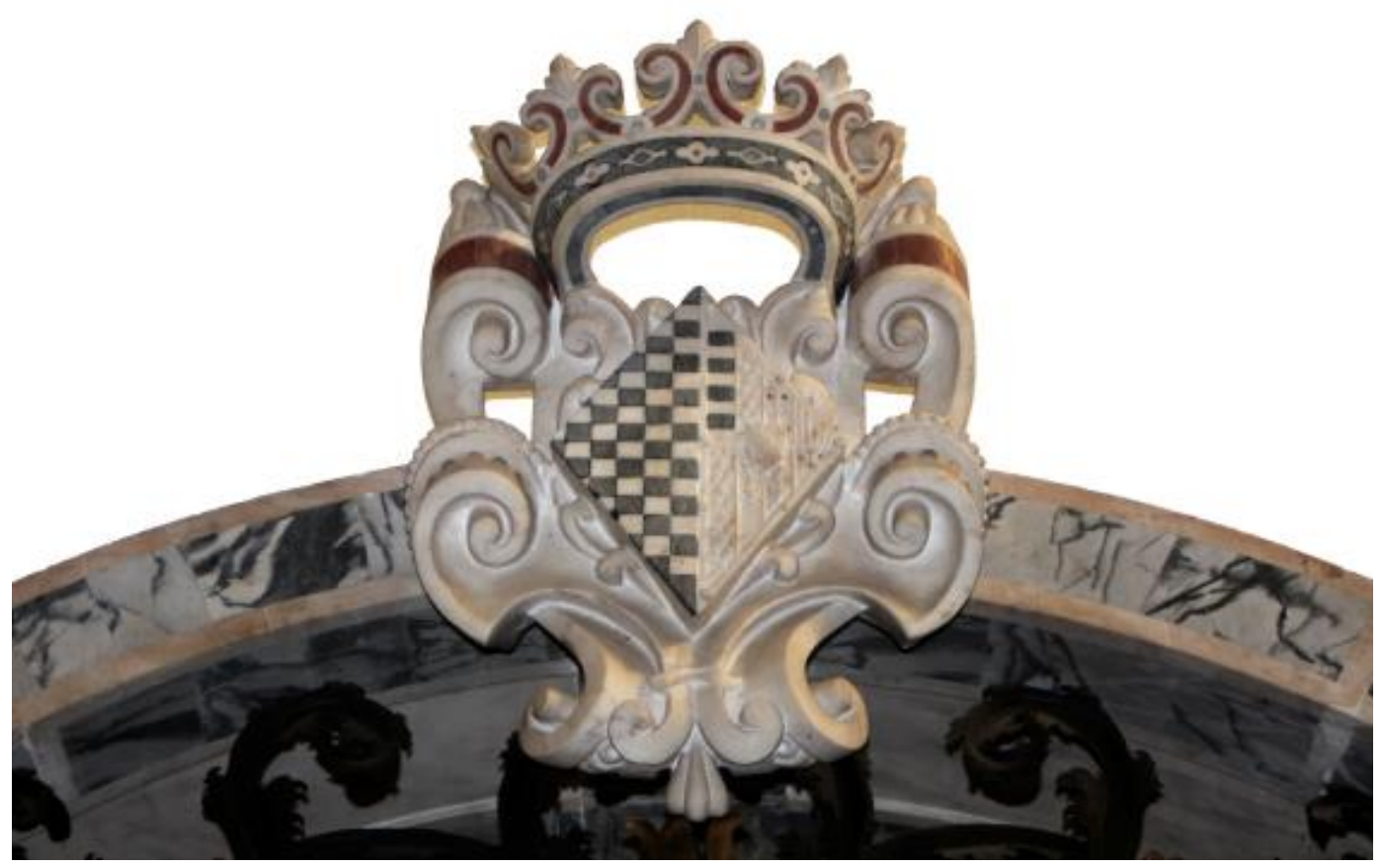

Figura 9. Ornamento em forma de coroa na Igreja do Espírito Santo. Os tons claros correspondem a mármores cremes de brancos de Estremoz o azul ao Ruivina e a cor avermelhada ao Lioz Encarnadão.

Neste grupo podemos ainda incluir, por também serem metamórficas e de menor dureza que as rochas siliciosas, os serpentinitos que são rochas verdes, com aspecto brechóide e são facilmente detetáveis por apresentarem uma cor de fundo verde-seco muito característica. Onde quer que tenham sido utilizadas contrastam com as que thes sejam adjacentes. Podem-se encontrar no altar principal da Sé de Évora, na Igreja do Convento do Espinheiro e na Igreja do Espírito Santo, por exemplo.

A aplicação no altar da Sé merece particular atenção (Figura 10). Uma análise detalhada revela alguns dados interessantes; antes de mais a simetria nos dois painéis em paredes opostas privilegia a cor em vez do material, assim o painel poente apresenta mármore azul de Trigaches (Figura 11) e o nascente mármore Ruivina de Estremoz (Figura 12).

Em relação à rocha verde, percebe-se que foi usada a técnica de polimento em livro aberto e desdobrado. Esta consiste em polir ambas as faces resultantes de um corte e aplica-las lado a lado, vertical e/ou horizontalmente. Desdobrado porque é percetível que o processo foi repetido várias vezes o que tornou possível que um fragmento relativamente pequeno possa ter originado placas suficientes para cobrir as áreas necessárias do painel. $O$ detalhe também mostra que pequenos fragmentos foram de igual modo utilizados (Figura 12), facto só por si revelador da preciosidade, por escassez, com que esta rocha era considerada.

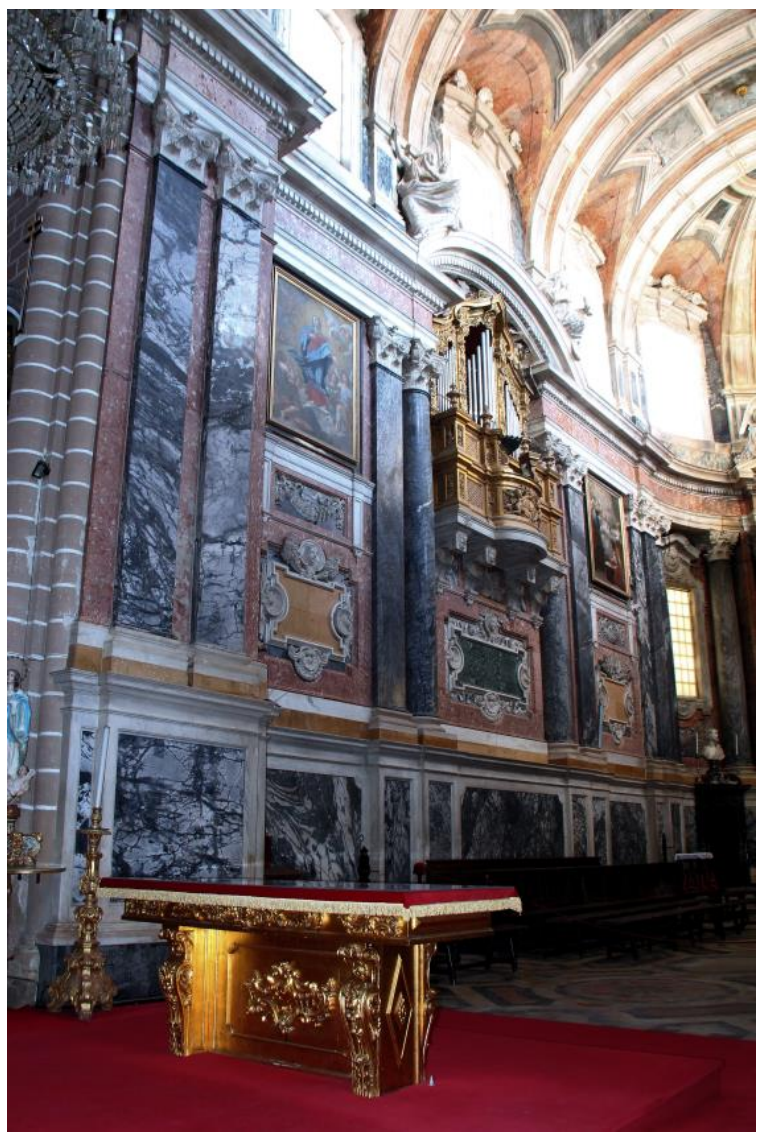

Figura 10. Vista geral do lado poente do altar da Sé Catedral de Évora (Igreja de Santa Maria). Destacam-se as colunas, placas retangulares verticais e os painéis inferiores (com dobras) em mármore ruivina escuro e vergado; dois painéis em amarelo de negrais e o painel mais trabalhado e com a brecha verde, sob o órgão. Rodeando todas as estruturas referidas está o Lioz, variedade Encarnadão. Os capitéis ricamente trabalhados são em mármore branco e creme de Estremoz. 


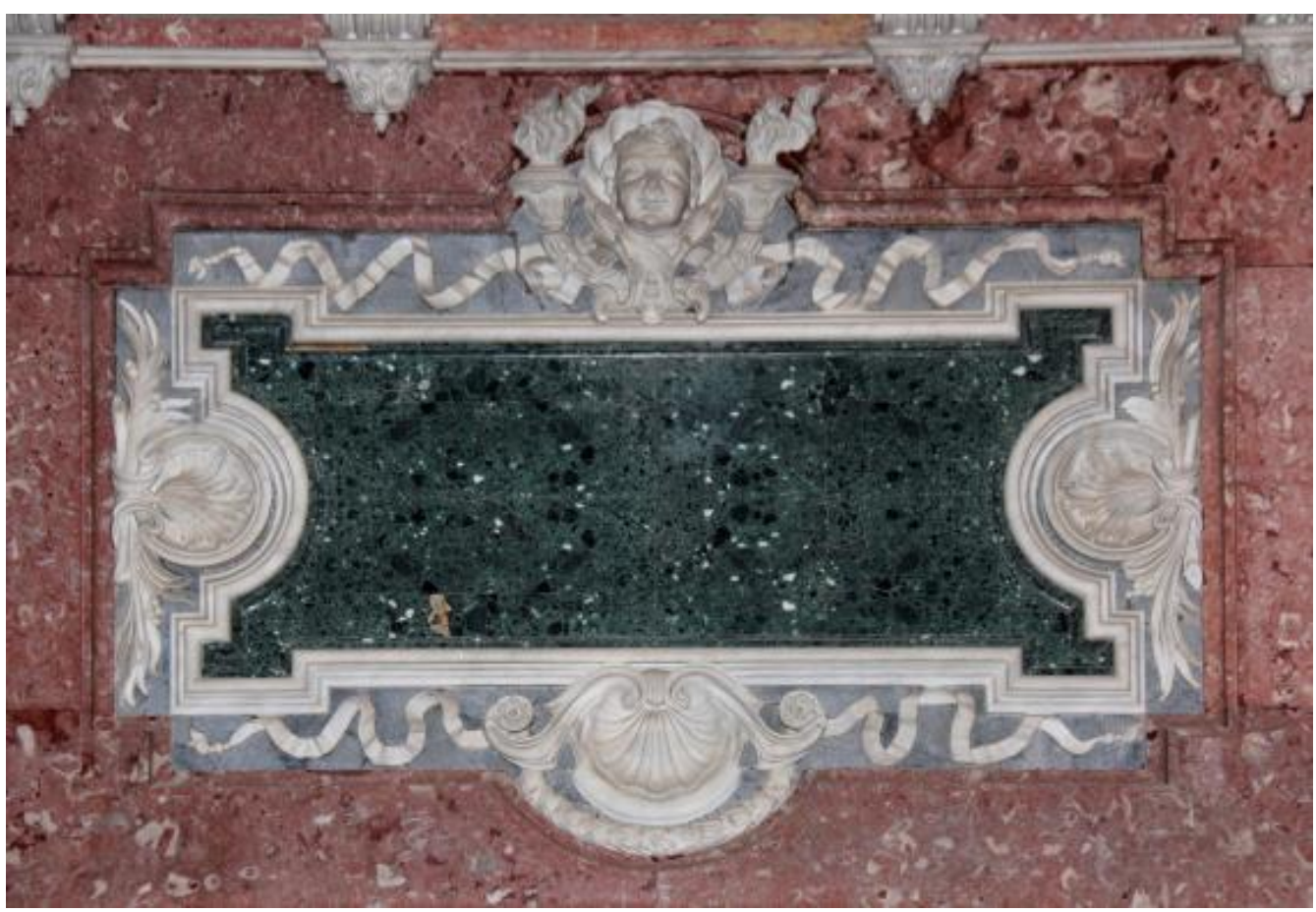

Figura 11. Painel ornamental sob o órgão no lado Noroeste do altar principal da Sé de Évora. Para além do "Verde Glaciale", que se destaca ao centro, apresenta mármore branco de Estremoz, mármore azul claro de Trigaches e calcário Lioz Encarnadão de Pêro Pinheiro.

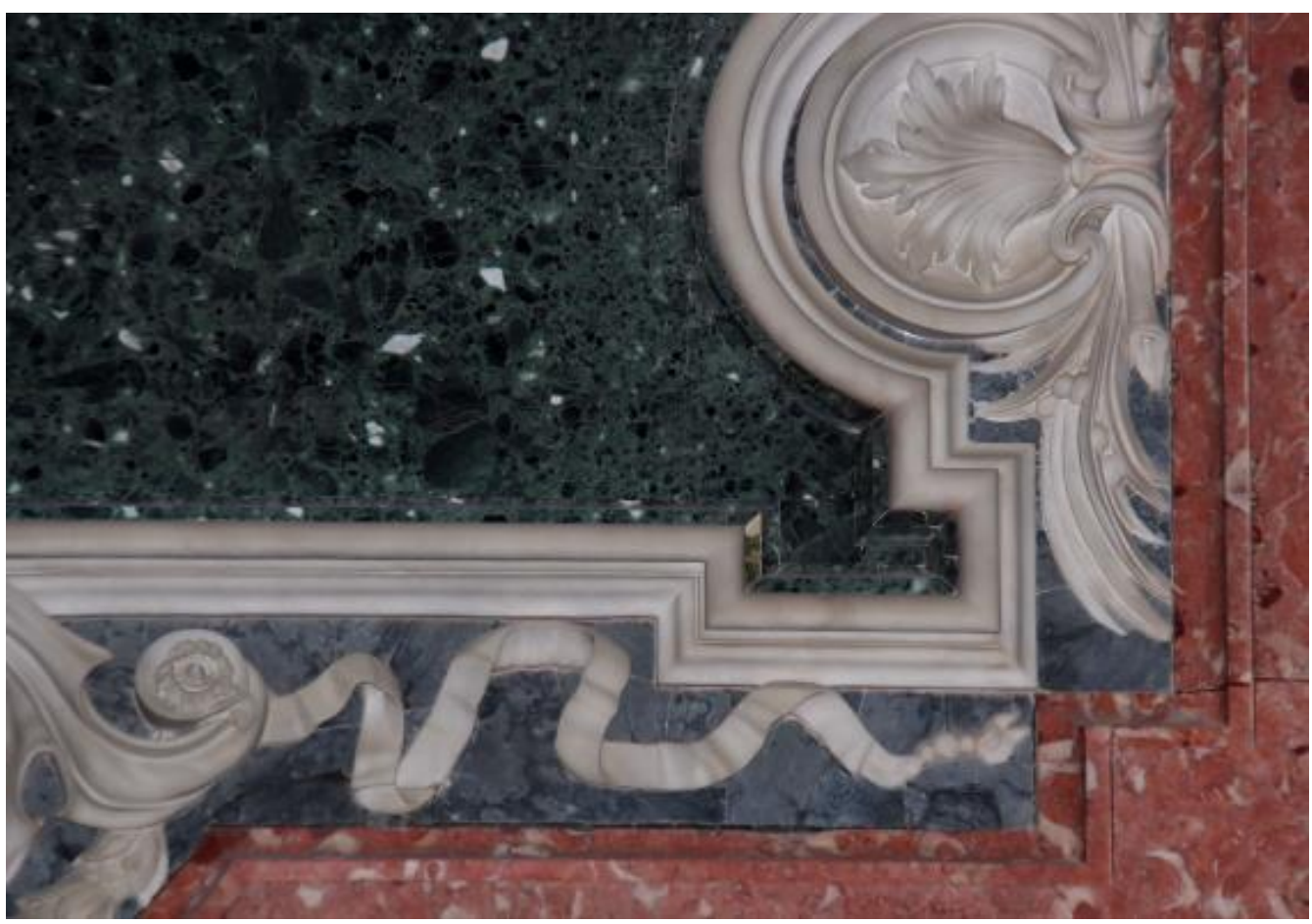

Figura 12. Pormenor do painel ornamental sob o órgão no lado direito (Sudeste) do altar principal da Sé de Évora. Aqui o mármore azul de Trigaches utilizado no outro painel é substituído por mármore Ruivina Claro de Estremoz. No Lioz destacam-se os fósseis brancos, lamelibrânquios (rudistas) muito característicos de todas as variedades cromáticas de Lioz.

Materiais similares a estes só foram explorados em Portugal no Séc. XX, mais intensamente entre os anos 60 e 80, na localidade de Donai, distrito de Bragança. A utilização destas rochas verdes em edifícios tão antigos, mesmo sem uma análise muito detalhada permite colocar a hipótese de que se trata de materiais importados muito provavelmente de Itália, onde no Norte ainda hoje se exploram, sob o nome de "Verde Glaciale". A título de exemplo podemos referir que foram intensamente utilizados em inúmeros monumentos do Renascimento Italiano, destacando-se pelo efeito estético resultante do contraste com o mármore branco de Carrara e pela imponência da estrutura, o Duomo de Florência. Também é interessante referir que apesar da secular indústria italiana de exploração de 
mármores nos Alpes Apuanos, na Toscânia mais precisamente entre Massa e Carrara, não encontramos nos Monumentos de Évora outros materiais cuja proveniência de Itália fosse provável. Ao contrário dos serpentinitos importados de Itália não é crível que os mármores de Carrara, ou de outro local circum-mediterrâneo, tivessem sido utilizados nos monumentos da Cidade de Évora. Todos os mármores identificados nos monumentos religiosos eborenses apresentam padrões, texturas e cores característicos dos mármores portugueses (Taelman et al., 2013).

Os xistos também são rochas metamórficas. Mais ou menos siliciosos, esverdeados, acinzentados ou "borra de vinho", são essencialmente utilizados nos pavimentos em conjunto com mármores de várias tonalidades definindo padrões e jogos de cor geometricamente disposto nos espaços que preenchem (Figura 13). Ocasionalmente, como acontece na igreja de São Mamede, foram utilizadas placas de grandes dimensões painéis colocados nas paredes (Figura 14).

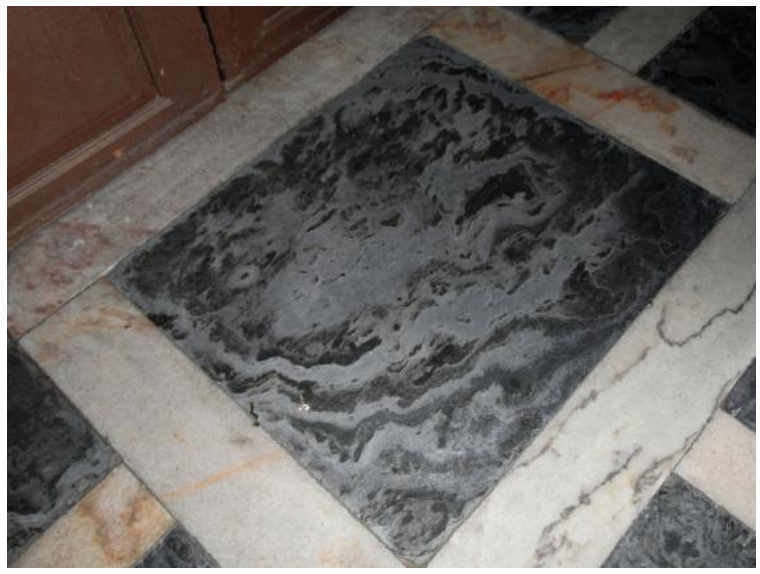

Figura 13. Igreja do Carmo. Pavimento revestido com xisto luzente e mármores indiferenciados.

3.3. Rochas sedimentares carbonatadas Calcários

Os calcários encontrados nos monumentos religiosos de Évora são rochas sedimentares carbonatadas que não existem no interior alentejano. As diversas variedades encontradas são provenientes da costa ocidental (geologicamente correspondente Orla Meso-Cenozoica Ocidental) onde ainda hoje se exploram. Destacamos os calcários cretácicos constituídos por fósseis de rudistas (bivalves) provenientes da região de Pêro Pinheiro - Sintra, genericamente designado por Lioz (Figuras 15 e 16). Apresenta-se nas variedades creme, encarnadão, cor-de-rosa, amarelo e mais raramente cinzento. Esta rocha ornamental desempenhou um papel histórico muito importante. Entre outras utilizações, está intrinsecamente associada à Expansão Marítima Portuguesa, à edificação do Convento de Mafra e à Reconstrução Pombalina de Lisboa.

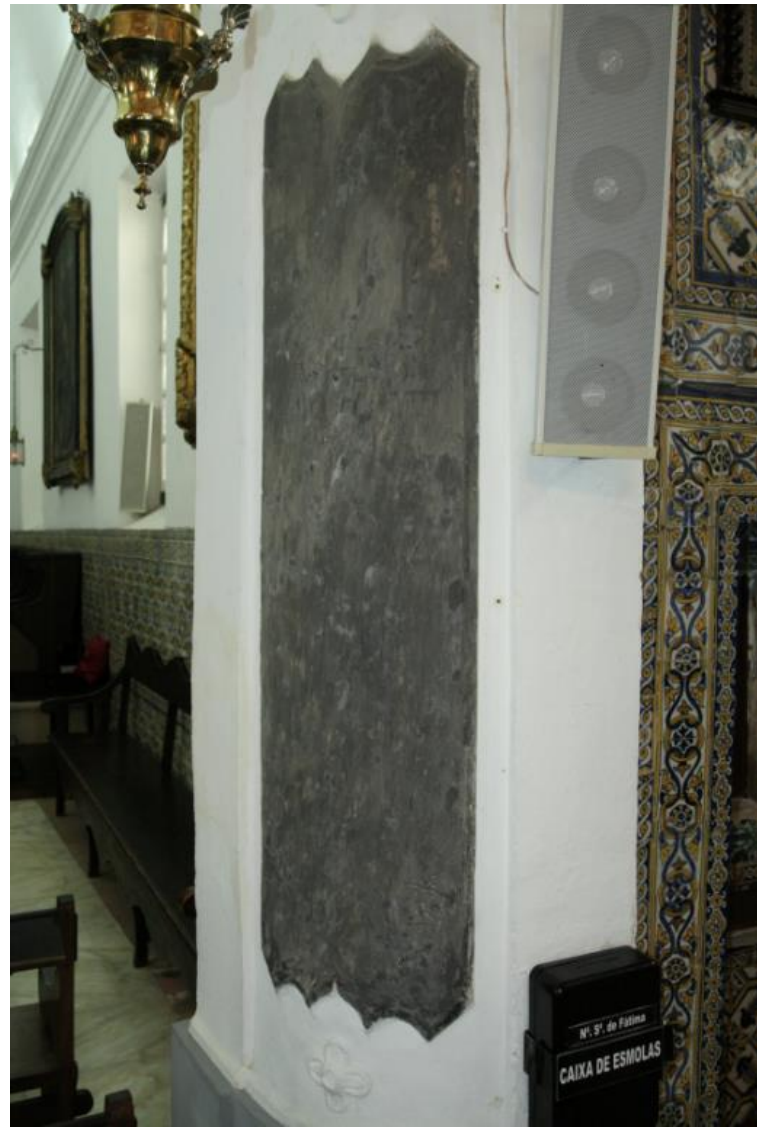

Figura 14. Igreja de São Mamede, painel em xisto. No Alentejo, placas de xisto de tão grandes dimensões são raras e a utilização nestes painéis é um reconhecimento dessa raridade. $\mathrm{Na}$ atualidade os ladrilhos de maiores dimensões são vendidos a um preço muito superior aos de menores dimensões, deste modo o tamanho das peças aplicadas surge como um indicador do poder económico do proprietário.

Efetivamente, estas rochas associadas a outros calcários, eram transformadas em altares e peças de cantaria que eram utilizadas com lastro das embarcações que zarpavam ao Novo Mundo (Silva, 2007). Chegados aos destinos serviam para ornamentar as igrejas que ainda hoje se podem encontrar, por exemplo na Bahia, Minas Gerais, Espírito Santo ou Rio de Janeiro, etc.

Estas rochas correspondem a calcários bio construídos ou seja, a antigas estruturas biológicas de rudistas, corais e outros invertebrados, que fixavam o carbonato de cálcio e assim iam edificando os recifes, tal como acontece hoje em dia. Há cerca de 97 milhões de anos isso ocorreu num local hoje correspondente à região de Lisboa e arredores (Pêro Pinheiro - Negrais - Sintra Cascais), razão pela qual a história da indústria da Pedra Ornamental em Portugal está tão enraizada naquela região, já que o núcleo extrativo e transformador de Pêro Pinheiro foi, até à década de 90 do Séc. XX, o mais importante do País. As mais 
importantes escolas de cantaria tinham aí a sua sede e tudo devido à ocorrência do Lioz no seu território. Esta rocha é pois parte integrante do património histórico português.

Outras rochas de natureza carbonatada também presentes nos monumentos eborenses e absolutamente inconfundíveis por apresentarem aspetos distintivos muito próprios são a "Brecha da Arrábida" (Figura 16) que não é mais do que uma brecha intraformacional do Jurássico médio constituído por fragmentos carbonatados multicolores e unidos por uma matriz também carbonatada e o Calcário Negro de Mem Martins (Figura 16). Como o nome indica, esta rocha apresenta uma cor negra absoluta devido ao teor elevado em matéria orgânica no entanto e apesar disso, ainda é suscetível de polimento devido à natureza microcristalina. Como elemento decorativo em conjunto com outros materiais também a podemos encontrar nos monumentos eborenses. Desde a década de 80 do Séc. XX que estes materiais não são explorados. A Brecha da Arrábida por apenas ocorrer no Parque Nacional da Arrábida e aí ter sido proibida a sua extração. A Pedreira do Jaspe, que foi das últimas a ser encerrada, permanece tal como foi abandonada sendo os indícios da atividade extrativa perfeitamente evidentes, é hoje um local visitável integrado nos percursos da natureza que o Parque promove. Quanto ao Calcário de Mem Martins apresentava reservas de reduzida dimensão que acabaram por ficar sob núcleos populacionais em resultado do crescimento urbano. A maestria dos canteiros portugueses revela-se quando combinam padrões, cores e texturas das várias rochas, realçando o melhor de cada uma num produto final esteticamente apelativo (Figuras $17 \mathrm{e}$ 18).

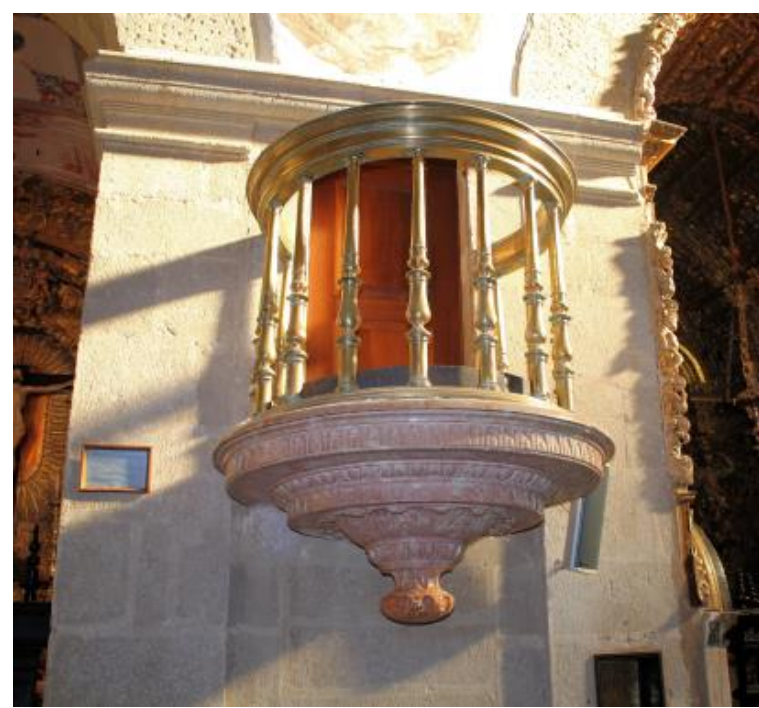

Figura 15. Igreja do Espírito Santo, púlpito com base em Lioz rosado ricamente trabalhado.

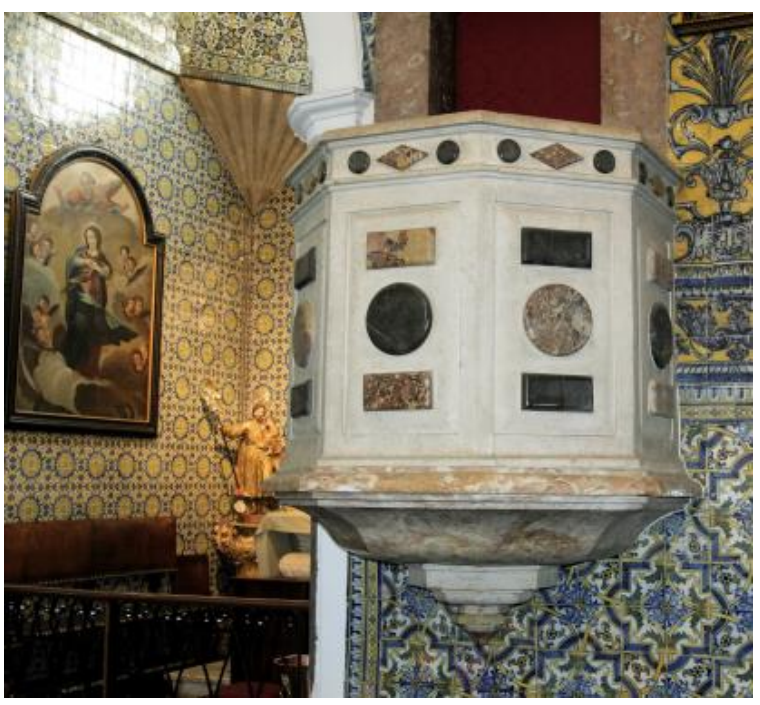

Figura 16. Igreja de São Mamede, púlpito em Lioz com ornamentos de Brecha da Arrábida e Calcário Negro de Mem Martins.

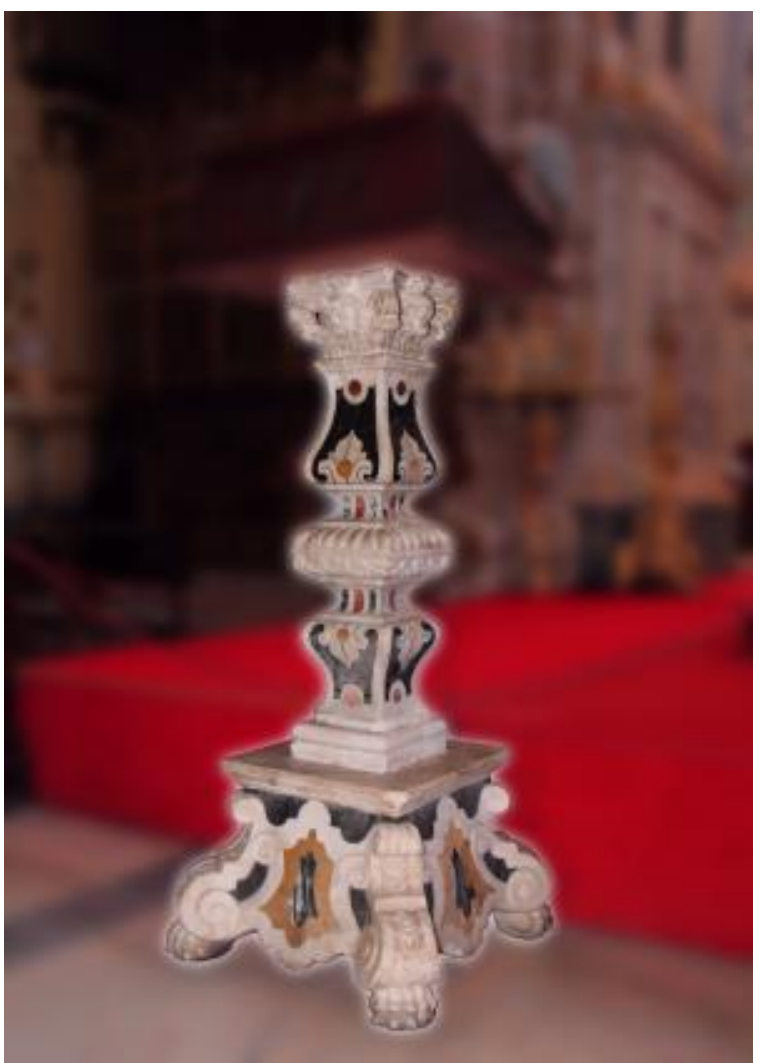

Figura 17. Sé de Évora, púlpito composto por mármores brancos e ruivina de Estremoz e calcários Amarelo de Negrais, Mem Martins e Lioz Encarnadão.

Erroneamente aplicados, por vezes encontram-se nos monumentos outras variedades de calcários tais como Alpinina, Vidraço, Ataíja, Moca Creme ou Moleanos, geralmente em obras de restauro ou ampliação mais recentes. Estes provêm do Maciço Calcário Estremenho e correspondem a unidades geológicas jurássicas distintas dos calcários da região de Lisboa que são cretácicas. 

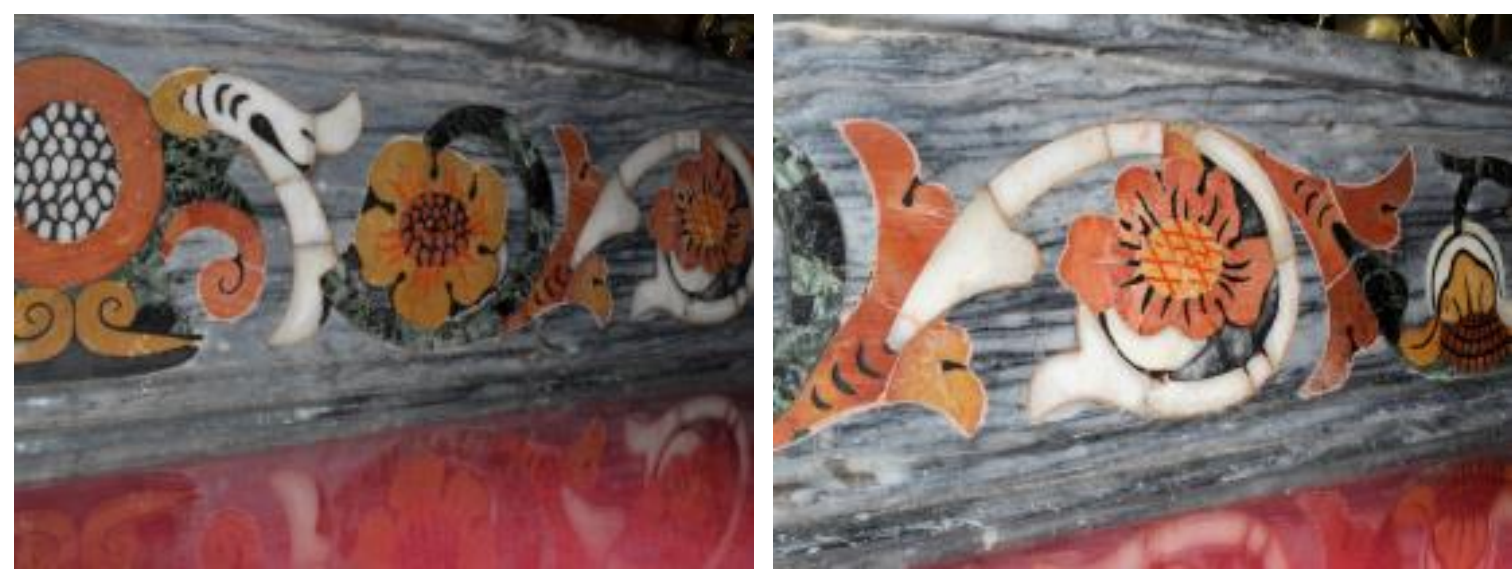

Figura 18. Friso na Igreja do Espírito Santo. Composto por serpentinito, mármore branco de Estremoz, calcários Amarelo Negrais, Negro de Mem Martins e Lioz Encarnadão num fundo de mármore Ruivina de Estremoz.

\section{CONCLUSÕES}

Em resumo, as pedras dos monumentos religiosos permitem reescrever a história da cidade numa perspetiva socioeconómica, histórica e arquitetónica que extravasa as fronteiras nacionais e não se esgota no emblemático Templo Romano (Figura 19).

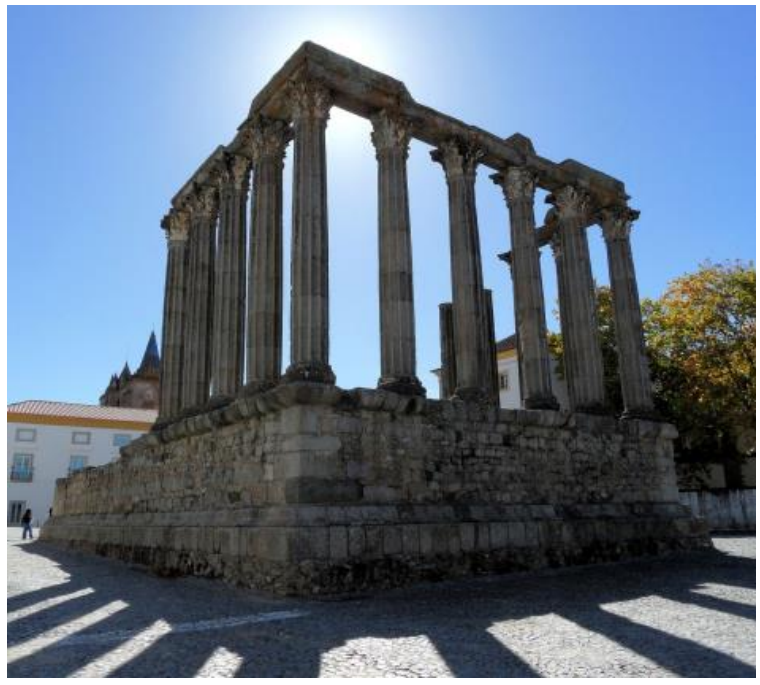

Figura 19. Templo Romano de Évora construído no Séc. I na então Liberatias lulia é por si só um repositório das rochas da região. Os capitéis e bases das colunas são de mármore branco de Estremoz, as restantes rochas siliciosas provêm de pedreiras romanas nos arredores de Évora.

A grande variedade de materiais utilizados ao longo do tempo implica uma continua transferência de materiais e conhecimentos a centenas ou mesmo milhares que quilómetros de distância. Contextualizando estas trocas no tempo ainda mais importância adquirem uma vez que exigiram esforços proporcionalmente muito superiores aos que hoje são necessários para o mesmo fim. Para efeitos de restauro, com exceção do Negro de Mem Martins, que pode ser substituído pelo "Nero Marquina" (País Basco - Espanha) ou pelo mármore Negro Belga (explorado pelo consórcio Luso-Belga
Solubema S.A./Merbes Sprimont S.A.), existem nas empresas portuguesas stocks consideráveis de todas as rochas ornamentais aqui referidas. Em Pêro Pinheiro foi mesmo recentemente retomada a atividade extrativa.

Sendo o património arquitectónico elemento mobilizador e fator de desenvolvimento regional, a sua preservação e/ou restauro quando necessário, é imprescindível e para tal é fundamental garantir a existência de matéria-prima para esses trabalhos de manutenção.

\section{REFERÊNCIAS BIBLIOGRÁFICAS}

CARVALHO, J.; LISBOA, J.; CASAL MOURA, A.; CARVALHO, C.; SOUSA, L.; MACHADO LEITE, M. Evaluation of the Portuguese ornamental stone resources. Rosa, L.; Silva, Z. \& Lopes, L. eds. Key Engineering Materials Vol. 548 (2013) pp 3-9. C) (2013) Trans Tech Publications, Switzerland. doi:10.4028/www.scientific.net/KEM.548.3.

CASAL MOURA, A., 2000. Granitos e Rochas Similares de Portugal, Instituto Geológico e Mineiro, Lisboa, ISBN 972-98469-5-2. $179 \mathrm{p}$.

CASAL MOURA, A.; CARVALHO, C.; ALMEIDA, I.; SAÚDE, J. G.; FARINHA RAMOS, J.; AUGUSTO, J.; RODRIGUES, J. D.; CARVALHO, J.; MARTINS, L.; MATOS; M. J.; MACHADO, M.; SOBREIRO, M. J.; PERES, M.; MARTINS, N.; BONITO, N.; HENRIQUES, P. \& SOBREIRO, S., 2007. Mármores e Calcários Ornamentais de Portugal. INETI (National Institute of Engineering, Technology and Innovation), ISBN 978-972-676204-1. 383 p.

ESPANCA, TÚLIO, Artes e Artistas em Évora no séc. 18, A cidade de Évora, vols. 21-22, Évora, 1950.

LOPES, L. 2017. As Rochas dos Monumentos de Évora. Livro Guia da Cidade de Évora. Câmara Municipal de Évora e Centro Hércules. In prep.

LOPES, L., CARRILHO LOPES, J. C., CABRAL, J. P. \& SARANTOPOULOS, P. 2000. Caracterização Petrográfica dos Monumentos Romanos de Évora. Revista "Cidade de Évora", II Série, №4. pp. 129-142.

SILVA, Z. C.2007. O Lioz Português de lastro de navio a arte na Bahia, Edições Afrontamento, Porto, ISBN 978-972-36-0924$0,156 \mathrm{p}$.

TAELMAN, D., ELBURG, M., SMET, I., DE PAEPE, P., LOPES, L., VANHAECKE, F., VERMEULEN, F. 2013. Roman Marble from 
Lusitânia: Petrographic and Geochemical Characterization, Journal of Archaeological Science, ISSN 0305-4403, http://dx.doi.org/10.1016/j.jas.2012.12.030.

\section{AGRADECIMENTO}

À organização do 10 Simpósio Brasileiro de Caracterização e Conservação da Pedra, o autor agradece o convite à participação nos trabalhos e apresentação em conferência do presente texto.
Contribuição ao

1‥ Simpósio Brasileiro de Caracterização e Conservação da Pedra 14 a 16 de dezembro de 2016, Congonhas - MG

\section{Nota:}

É de responsabilidade da comissão editorial do Simpósio a revisão gramatical, ortográfica, de citações e referências bibliográficas. As normas de submissão podem se diferenciar das desta revista. 